\title{
Erratum to: SDF1 in the dorsal corticospinal tract promotes CXCR4+ cell migration after spinal cord injury
}

Vicki M. Tysseling ${ }^{1 *}$, Divakar S. Mithal ${ }^{2}$, Vibhu Sahni ${ }^{1}$, Derin Birch ${ }^{1}$, Hosung Jung ${ }^{2}$, Richard J. Miller ${ }^{2}$ and John A. Kessler ${ }^{1}$

\section{Erratum}

During production of the original article [1], Divakar Singh Mithal's middle initial was omitted, and listed as 'Mithal D'. The correct attribution is 'Mithal DS'.

\section{Author details \\ 'Department of Neurology, Northwestern University's Feinberg School of Medicine, Chicago, IL 60611, USA. ${ }^{2}$ Department of Molecular Pharmacology and Biological Chemistry, Northwestern University's Feinberg School of Medicine, Chicago, IL 60611, USA.}

Received: 1 February 2017 Accepted: 7 February 2017

Published online: 14 February 2017

\section{Reference}

1. Tysseling VM, Mithal DS, Sahni V, Birch D, Jung H, Miller RJ, Kessler JA. SDF1 in the dorsal corticospinal tract promotes CXCR4+ cell migration after spinal cord injury. BMC Journal of Neuroinflammation. 2011;8:16. doi:10.1186/1742-2094-8-16. 